\section{DIGITAL COMMONS \\ @ UNIVERSITY OF SOUTH FLORIDA}

\section{ABO: Interactive Journal for Women in the Arts, 1640-1830}

Volume 8

Issue 2 Volume 8, Issue 2 Fall 2018

Article 1

2018

\title{
New Lines: Mary Ann Yates, The Orphan of China, and the New She-tragedy
}

\author{
Elaine McGirr \\ University of Bristol, elaine.mcgirr@bristol.ac.uk
}

Follow this and additional works at: https://digitalcommons.usf.edu/abo

Part of the Acting Commons, Dramatic Literature, Criticism and Theory Commons, Education Commons, Literature in English, British Isles Commons, and the Women's Studies Commons

\section{Recommended Citation}

McGirr, Elaine (2018) "New Lines: Mary Ann Yates, The Orphan of China, and the New She-tragedy," $A B O$ : Interactive Journal for Women in the Arts, 1640-1830: Vol.8: Iss.2, Article 1.

https://doi.org/10.5038/2157-7129.8.2.1198

Available at: https://digitalcommons.usf.edu/abo/vol8/iss2/1

This Scholarship is brought to you for free and open access by Digital Commons @ University of South Florida. It has been accepted for inclusion in ABO: Interactive Journal for Women in the Arts, 1640-1830 by an authorized administrator of Digital Commons @ University of South Florida. For more information, please contact digitalcommons@usf.edu. 


\title{
New Lines: Mary Ann Yates, The Orphan of China, and the New She-tragedy
}

\begin{abstract}
This essay demonstrates a significant break in eighteenth-century tragedy from tales of fallen women begging (the audience) for forgiveness and redemption to a different kind of she-tragedy, in which the heroine is neither fallen nor sexually desired, but rather transcends nation and politics with the "natural" moral force of maternal love. I argue that this shift was made possible/legible by Susannah Cibber's illhealth, which forced Arthur Murphy to reconceive The Orphan of China's heroine and allowed a rival actress, Mary Ann Yates, to step into this new role and to establish a tragic 'line' defined in opposition to that of her predecessor. The essay demonstrates this shift by tracing The Orphan of China's convoluted path to the stage and by reading Murphy's tragedy in dialogue with earlier translations of The Orphan of China and Douglas, the play Covent Garden mounted in opposition to The Orphan of China.
\end{abstract}

\section{Creative Commons License}

(c) (1) (9)

This work is licensed under a Creative Commons Attribution-Noncommercial 4.0 License

\section{Cover Page Footnote}

I would like to thank the students of Royal Holloway's Department of Drama, whose initial work with The Orphan of China was the genesis for this essay. 
The mid-eighteenth century stage is marked more by tradition than revolution. Actor-managers were loath to take risks with new plays, new players, or new styles. The repertory system privileged established audience favourites, plays and players alike. New plays were risky, and if the risk-averse Theatres Royal in London had to have new work, they preferred their new plays to be by established playwrights, in established genres, with established performers. The conservatism of the theatre extended to performance practice: actors held on to their parts for the duration of their careers, and new actors had their parts handed down to them in both substance and style. It was an extraordinary actor who could break through these layers of tradition to create something new. David Garrick (1717-1779) was one such actor. Mary Ann Yates (1728-1787) was another. Yates's breakthrough is all the more remarkable because her star vehicle was a new play by a new playwright: Arthur Murphy's The Orphan of China (1759). ${ }^{1}$ Mary Ann Yates's success in this play turned the useful understudy into a celebrity tragedienne and led to a second wave of she-tragedy, as playwrights hastened to write for the new star and her new style. Yates's performance in The Orphan of China thus led to a significant development in eighteenth-century drama, for not only did Yates replace the celebrated Susannah Cibber in Murphy's tragedy, but she also replaced Cibber as the Muse of Tragedy, which was refashioned in Yates's sterner, majestic, image. ${ }^{2}$ The new she-tragedies portrayed women as agents of justice rather than objects of pity; queens who may still be "unfortunate," but also "seemed to triumph over all [their] enemies" (Davies 132). ${ }^{3}$

Yates's breakthrough performance came in a new play, but the novelty of Murphy's tragedy was as surprising as that of Yates's performance. The Orphan of China is not an original story, but an adaptation of Voltaire's L'Orphelin de la Chine (1755), itself a translation of The Orphan of Zhao. Translating or adapting an established play was one of the most common forms of 'new' writing, with classical texts and French dramas proving most acceptable to the managers of Drury Lane and Covent Garden. Moliere, Racine and Voltaire were all mined for their plots and characters, and the success (and sometimes failure) of a French play was a good barometer for its success in an English dress. ${ }^{4}$ Given this well-established tradition of translation, it is perhaps less surprising that Murphy's tragedy was staged, and instead more so that its journey from the Parisian to the London stage took so long and was so fraught. The play took four years and countless rewrites as well as significant cast changes before Voltaire's L'Orphelin de la Chine premiered as Arthur Murphy's Orphan of China. ${ }^{5}$ This lengthy development period led to significant changes in the play's plot and emotional impact, changes made legible through Mary Ann Yates's performance. By reading Murphy's rewriting of the orphan of Zhao story in dialogue with its earlier translations, we see how playwright and actor collaborated to create a wholly new play and a new kind of tragic heroine. We see the extent of this radical departure by comparing it to Douglas (1755), the play Covent Garden mounted in opposition to The Orphan of China. The head-to-head rivalry between the Theatres Royal firmly established Mary Ann Yates's rising star. By the following season, Mary Ann Yates was not only The Orphan of China's Mandane, but Douglas's Lady Randolph as well.

\section{From Voltaire's L'Orphelin de la Chine to Arthur Murphy's Orphan of China (1755-59)}

The Orphan of China was first introduced to London audiences on 19 December 1755, through advertisements for an anonymous ${ }^{6}$ publication of The Orphan of China, "Translated from the French of M. De Voltaire. Acted at Paris with great Applause" (Public Advertiser, 19 Dec 1755). Subsequent advertisements followed, and the publicity paid off: the translation was extremely successful, running through three London editions and a (pirated) Dublin edition in 
1756 alone. The Orphan of China had proved popular with readers; surely theatre-goers would be similarly captivated.

This is clearly what Thomas Francklin believed when he published his translation with a fulsome dedication to David Garrick, observing that:

The Story of Voltaire's ORPHAN of CHINA, is so very affecting, and some of the characters so strongly marked, that I cannot help taking this method of recommending it to your notice. A Play built on the same Fable, could not fail of being well received on our Stage. The following Translation, lame as it may appear, would bid fair for as many admirers as most of our modern Tragedies, if ZAMTI was represented by Mr. Garrick, and IDAME by Mrs Cibber ... (iii)

However, he goes on to add that "If you seriously intended to bring on a Tragedy founded in this Story, some few alterations in the Plan might be made, which, I think, would render it still more excellent" (iv). ${ }^{7}$ Voltaire's version of the Orphan of Zhao story is an Orientalist romance that dramatizes Ghengis Khan's conversion from barbarity and tyranny to 'good' colonial rule through the mediation of Zamti's wife Idame. Orphelin's dramatic energy focuses on the civilising power of love: Ghengis Khan's unruly passion for Idame is reformed from lust to admiration by recognising and valuing her conjugal love for Zamti and her equally virtuous love for her nation and its legitimate ruling family, represented by the eponymous infant Orphan. Genghis Kahn learns to desire the fidelity Idame shows her husband and state more than Idame's person. He is reformed, and vows to obey the rule of law.

This brief overview should explain the appeal of Voltaire's play to the mid-eighteenth-century British stage, which had an insatiable appetite for she-tragedy, Orientalist tragedy, and nationalist/imperial fantasy. ${ }^{8}$ Orphelin de la Chine seemed to tick all of the boxes, as Francklin suggests in his imagined casting of Garrick and Cibber. David Garrick and Susannah Cibber were the nation's favourite tragic couple, regularly reducing audiences to tears in Romeo and Juliet, Tancred and Sigismunda, Venice Preserv'd and a score of other plays. The character of Zamti, the loyal subject willing to defy the Mongolian tyrant and to sacrifice his son for the good of the state is an appealing addition to Garrick's line of tragic heroes. In suggesting alterations to Voltaire's plotting, the aspiring playwright may have spotted Garrick's primary objection to the play: in Voltaire's version of the story, Zamti is a hero, but not the play's dramatic focus. Garrick was sensitive to the overlap between stage and celebrity personae, and preferred heroic lovers to barbaric tyrants - for instance, he performed the Christian king Lusigan in Aaron Hill's Zara in preference to the murderous Osmyn, despite the former's limited stage time. ${ }^{9}$ Perhaps this is why Garrick did not take up Francklin's Orphan even when the print sales seemed to justify a production.

Garrick ignored Francklin's bid for preferment, but the popularity of the story seemed to justify another attempt. Arthur Murphy, a protégé of Colley Cibber's, offered Garrick an Orphan of China in November 1756. It also failed to find favour with Garrick, but was not rejected outright. ${ }^{10}$ Murphy spent the next two and a half years revising the play and lobbying for its production, calling in the patronage of Horace Walpole and Henry Fox, and finally agreeing to have the play reviewed by William Whitehead, who, as the new poet laureate, was to act as an arbiter of taste and quality. ${ }^{11}$ By January of 1759 , Murphy was desperate to see his play produced, writing to Garrick: "What can you mean by its present state? Do you mean without the alteration of a line, or the insertion of a line, or any slight alteration that can be expeditiously made, allowing such alteration should be deemed reasonable? Things of this sort I am, and ever 
was willing to do ..." (qtd. in Boaden 96) and "I could wish to see the play acted as near as possible to the copy which Mr Whitehead approved" (qtd. in Boaden 98). He hastened to add that he had made Zamti - Garrick's role - the "capital part" (qtd. in Boaden 98). The play was finally approved for performance and scheduled for the spring of 1759, by which point it was a very different tragedy to the previously published translations, which followed the French version of the story.

However, there were more problems in bringing The Orphan of China to the stage than Garrick's issues with Murphy's translation and dramaturgy. There were also problems with casting. Susannah Cibber, Murphy's and Garrick's Idame of choice, had shot to fame in 1736 as the title character in Aaron Hill's adaptation of Voltaire's Zaire. The catastrophic and public breakdown of her marriage two years later did little to damage her reputation-rather increasing the verisimilitude of her performances of suffering yet passionate women. Voltaire's Idame, the unfortunate beloved of Ghengis Khan, was a perfect addition to her line of passionately suffering heroines. But in 1759, the forty-five-year-old actress was suffering from an acute stomach complaint that restricted her ability to perform. Murphy wrote to Garrick in January 1759 that "Mr. Cross tells me Mrs. Cibber will not be able to perform: if so, with the consent of the managers, I would wait on Mrs. Pritchard, who is a very acceptable actress to the public. If Mrs. Cibber is not so ill as to resign her part, I think for fear of accidents, you should order the part to be under-studied, by Mrs. Yates, as has been the general practice. This I mention, as I find it is not done, and there is little time to lose" (qtd. in Boaden 98-99). Despite being the most popular and highest-paid actress at Drury Lane, Susannah Cibber made only thirty-five known appearances in the 1758-59 season, which lasted 172 nights. The season was not especially good for tragedy, perhaps due to Cibber's ill-health. A revival of Antony and Cleopatra with Garrick as Antony and Mary Ann Yates as Cleopatra limped through five nonconsecutive performances, with Cross, the prompter, drily noting, "This Play tho' all new dress'd and had Fine Scenes did not seem to give ye Audience any great pleasure, or draw any Applause" (qtd. in Stone 704). ${ }^{12}$ A revival of The Ambitious Stepmother in February managed a further four performances after Cibber was forced to withdraw from the lead. Her illness meant that Cibber's signature role, Zara, was replaced with the Pritchard vehicle Creusa, but that only managed two performances. The only other tragedy that spring was a revised production of Mallet's Eurydice with Cibber in the title role, which Cross dismissed as "dull" (qtd. in Stone 713). Mallet went further, complaining that his revised tragedy failed as a direct result of a performer's "negligence" regarding pathos, Cibber's stock-in-trade (Baker 207.). She seems to have failed in a role literally written for her: Eurydice only managed four nights. Perhaps recognising her diminished powers, Cibber took on no new parts in the 1758-59 season, a decision she was able to take due to her celebrity status and continuing value to Drury Lane, despite her failing health. Cibber's contract gave her several perks and privileges, including the right of first refusal over all new roles. ${ }^{13}$ Although intended as a positive choice, in practice this meant Cibber could dictate how tragic parts were cast. She used this power to ensure that the female lead in Murphy's tragedy did not go to her established rival, Mrs Pritchard, but rather was passed down to her supposedly unthreatening understudy, Mary Ann Yates.

\section{Generic ambiguity in Arthur Murphy's The Orphan of China (1759)}

Murphy's Orphan of China is a radically different play from Voltaire's, and also radically different from the serious dramas typical of the period. The Orphan of China is double-plotted, but even this structural similarity exposes generic innovation. Murphy's Orphan of China is not a tragi-comedy: there is no low plot. Instead, the play smuggles a domestic tragedy into a 
nationalist frame. It combines she-tragedy and heroic drama, rewriting both genres in the process. Murphy's Orphan of China, like its source text(s) and many popular eighteenthcentury tragedies, is a chronologically and geographically displaced fable about tyranny and rebellion, about religious and cultural oppression, and about the competing demands of private love and public duty. But the new Orphan of China is set twenty years after the action of Voltaire's drama. Murphy's play tells the story of the effects of the foreign invasion of China and dramatizes the restoration, rather than loss, of the eponymous "orphan" prince. The heroic plot focuses on this public drama, detailing the mandarin Zamti's zealous protection of the prince Zaphimri, the rightful heir to the Chinese throne. It follows Zamti's plot to overthrow the Mongolian tyrant, Timurkan (the renamed Ghengis Khan character), leading to the triumphant return of right rule and religion. The domestic plot, on the other hand, complicates this straightforward narrative by drawing out the complicated interrelationships between this heroic tale and a private tragedy of parental loss. This plot centers on Mandane (the renamed Idame) and the title character(s), recoloring the play's triumphalist narrative with a deep history of personal and political trauma. By moving the action of his tragedy twenty years forward from Voltaire's, Murphy creates an alternative history. In Murphy's China, Zamti has heroically saved the royal orphan, Zaphimri by taking him into his home and raising him as his child, disguised under the name Etan. To make this ruse effective, Zamti has sent his real infant son, Hamet, to be raised in exile, unaware of his true identity. The Orphan of China dramatizes the resolution of this double displacement and reveals the true identities of both boys, now young men. The play begins in media res, as a rebellion against the usurping Mongols attempts to reverse the original invasion. When the play opens, the rebellion appears to have failed and the Mongols have captured its leader, who is assumed to be the 'lost' orphan prince of ChinaZaphimri/Etan. Timurkan vows to crush the rebellion by executing the captive. But of course the captured warrior is not the blood prince of China but rather Zamti's exiled son, Hamet. His success in battle led the Mongols - and Hamet himself - to misrecognise him as the orphan of China, but his parents know their son and the identity of the real prince. Zamti believes that the overthrow of the Mongolian tyrant necessitates a second sacrifice of Hamet: he wants Mandane to confirm Timurkan's misrecognition of her son as the 'Orphan' to keep the real prince safe. But when Mandane is told that she must sacrifice her son - again - for the good of her nation, she refuses, exposing both boys to danger and threatening the success of the rebellion. If the heroic plot offers the traditional binary of love / honour, then the domestic plot emphasises the fragility of interpersonal relations and suggests that "Orphan" is a role, rather than a fixed identity. Mandane cuts through this dilemma by declaring that both boys are her sons: her maternal love means there need be no Orphan of China. She refuses to compromise; she will not choose between blood and nation or stoically sacrifice the personal for the public good. By rejecting the false binary of love or honour, she is able to save both the boys and the nation: Timurkan is overthrown and both the son she raised and the son to whom she gave birth live. Her rejection of Zamti's argument for public virtue is what leads to the prince's restoration. More importantly, Mandane's sacrifice breaks the heroic cycle and teaches both boys-and through them, the audience - that love and duty can, and indeed must, coexist. Hamet and Zaphimri close the play outlining a hopeful future for China that blends affection and duty.

The Orphan of China thus draws on the structure of both she-tragedy and heroic drama in order to undermine the moral certainties of both: like the heroic, its plot turns on the tension between private love and public duty; as in she-tragedy, the passionate fault of the female lead brings chaos. But The Orphan of China inverts the consequences of both the heroic's deep suspicion of private love and she-tragedy's punishment of female agency and passion. Unlike the denouements typical of both the heroic and she-tragedy, The Orphan of China does not expose a dynastic crisis: the play ends with a new generation of rulers and viziers pledged to mutual 
love and support. The state is restored, and is more stable than ever. The Orphan of China also validates the feminine passion that precipitates the play's crisis: Mandane's privileging of the domestic over the national leads to the nation's salvation. Mandane dies, but her death is not in expiation of her passionate fault, but rather a Christic act of self-sacrifice that preserves her beloved boys and saves the state.

After years of dramaturgical intervention and months of casting issues, Murphy's tragedy finally premiered on 21 April 1759. The Orphan of China was a modest hit for Drury Lane with at least 10 performances, ${ }^{14}$ which made it the most successful tragedy of the season. ${ }^{15}$ David Garrick wanted The Orphan of China to be another Garrick star vehicle: he played the carefully re-written Zamti, whose loyalty to his state, his religion, and his monarch even under a tyrant's yoke, allows him to shine heroically to both ends of the political spectrum. Garrick's objections to Murphy's script were at least in part objections to the writing of this role. ${ }^{16}$ Zamti is given valuable stage time and clap-traps such as his "Dream on, deluded tyrant" soliloquy at the close of Act 2 and his spectacular - and lengthy - death scene in Act 5. Garrick's confidence that the new tragedy would pay even without his star tragedienne is further evidence that he envisioned the play as heroic drama rather than she-tragedy. But Garrick's carefully orchestrated play-doctoring did not go to plan. Theatrical optics and repertory rivalries combined to redirect audience attention away from the peerless Zamti and on to the play's tragic heroine, Mandane, played by Mary Ann Yates.

At first glance, this is not surprising. Mandane is the only female character and only role performed by an actress in the play. ${ }^{17}$ This singularity ensured that Mandane would always be an object of interest, especially to mid-eighteenth-century audiences raised on she-tragedy. The costuming, especially Mandane's Chinoiserie robes, encouraged a consuming gaze. ${ }^{18}$ But Manadane's appeal did not lie solely in her spectacular costume: her character, and particularly its embodiment in Yates's performance, offered audiences a new way of seeing she-tragedy. Yates's Mandane seemed to demand a new gaze, a new affective relationship, from the audience. As the plot synopsis above demonstrates, the play is not structured like the period's she-tragedies; although Mandane is passionate, the play resolutely avoids romantic love. But rather than shift attention away from the tragedy's sole female character and her story, as Garrick presumably expected, this focus encouraged audiences to see her as something other than an object of desire, to recognize her as a new kind of heroine. This shift was made more legible through performance: audiences encountered this new character in a comparatively new actress. For while Yates had been part of the Drury Lane company since 1755, she had only taken on established roles in revivals or come on as an understudy. This was the first character she created.

Susannah Cibber's well-established tragic line was a pathos-laden blend of chaste and romantic love. She excelled in attracting the male gaze without overstepping the bounds of decency by playing innocent sufferers, women more sinned against than sinning. She was Desdemona and Ophelia, Perdita and Monimia, Lady Brute and Indiana. It is likely that Idame/Mandane was originally intended to fit this mould: a passionate, suffering woman audiences would be expected to pity, but not to celebrate. This is Idame's character in the 1755 translation offered to Garrick as a vehicle for himself and Mrs Cibber. Idame is "Still fairer, and more beautiful in grief" (Francklin III.i.9). She begs Ghengis Khan, and through him, the audience, to "punish me; who have at once betray'd / My husband and my king" (Francklin III.iii.55-56). But Mandane is a very different character. She rejects the audience's pity and demands-and 
receives - admiration from all, on-stage and off. She doesn't ask to be punished; she demands justice.

The success of Orphan of China and of Mary Ann Yates, whose performance as Mandane transformed her from Mrs. Cibber's understudy to the pre-eminent tragedienne of the period, should be attributed to Mandane's - and Mrs. Yates's - radical departure from the established tragic line of suffering victims. Not only does Mandane depart from Susannah Cibber's line of wronged wives and bereaved mothers, but she also diverges from tragic convention and Murphy's source text by eschewing a love plot. Mandane is not guilty of sexual crimes or even indiscretions. She has not entered into a secret marriage or given her love unwisely. She has not committed adultery, even unintentionally. She is not mourning a lost lover. She is a faithful wife and mother defined as a nurturing rather than erotic object. Unlike Voltaire's Idame, who retains the beauty that once held Ghengis Khan in its chains, Mandane is not presented as a universal beauty or an object of lust, envy, or desire. Instead, she assures audiences that twenty years of care and sacrifice have "wither'd [her] bloom"; her "wasted form" and "faded eyes" scorn the "nuptial bed" (Murphy 31). The original sacrifice of her child has physically and psychically marked her. Given the protracted nature of Murphy's revision process, it is impossible to pinpoint when Voltaire's Idame became Murphy's Mandane, but the change in actress materially affected the characterisation. Marvin Carlson reminds us that " $\mathrm{t}] \mathrm{he}$ recycled body of an actor, already a complex bearer of semiotic messages, will almost inevitably in a new role evoke the ghost or ghosts of previous roles if they have made any impression whatever on the audience, a phenomenon that often colors and indeed may dominate the reception process" (8). Given Susannah Cibber's established 'line,' her famously soft and moving delivery and her slight figure, her complaints of Mandane's lost beauty would prompt audiences to envision Cibber in her prime - as the 1755/6 translation of Orphan of China does explicitly. David Erskine Baker describes Cibber as "perfectly elegant; for although somewhat declined beyond the bloom of youth, and even want[ing] that Embonpoint which sometimes is assistant in concealing the impression made by the hand of time, yet there was so compleat a symmetry and proportion in the different parts which constituted this lady's form, that it was impossible to view her figure and not think her young, or look in her face and not consider her handsome" (84). Susannah Cibber's illness also lends verisimilitude to Mandane's lines: the petite actress's failing health marked her already slight body. The 45-year-old Cibber was "wasted" by the illness affecting her digestion, leaving her physically frail. Mary Ann Yates brought none of this to the character. The thirty-one-year-old actress was Susannah Cibber's opposite in many respects: Yates was strong where Cibber was soft, physically imposing rather than delicate, and although both were known for their low, musical voices, Yates's delivery was forceful where Cibber's was pathetic. Where Cibber melted, Yates burned. Where Cibber pleaded, Yates commanded. The distinction between the two tragediennes is clear in their portraiture: Cibber's small supple body adopts the serpentine curves lauded by Hogarth as "the line of Beauty"; conversely, Yates stands straight and tall and gestures in right angles and perpendicular lines (see fig. 1 and fig. 2). A Cibberian Mandane, like the Cibberian Cordelia, the Cibberian Ophelia, and the Cibberian Constance, would have sunk gracefully into madness and sorrow. In Yates's interpretation, Mandane rises rather than falls: she is an avenging fury demanding Justice, not mercy. 


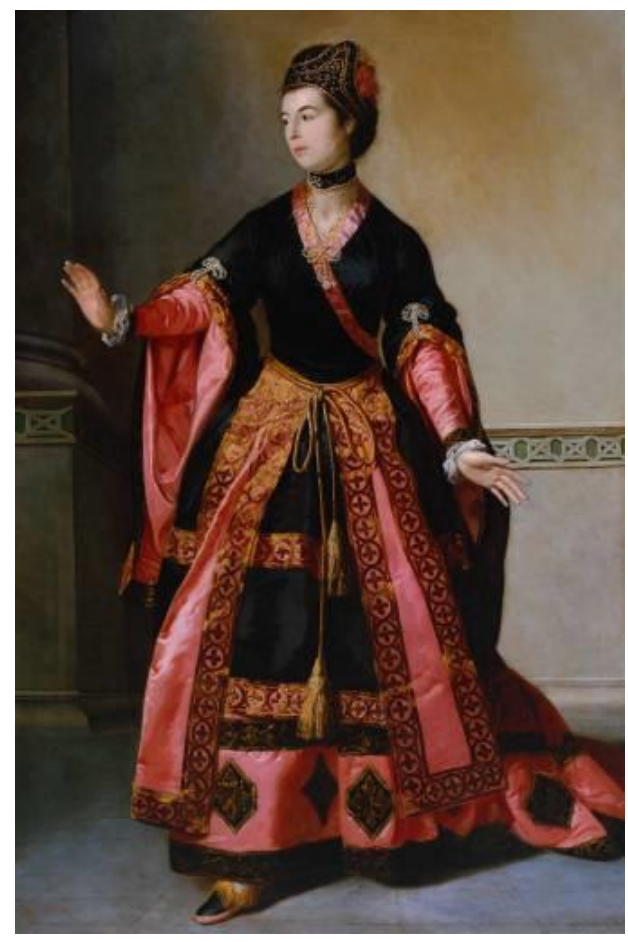

Figure 1: Mrs. Yates in the character of Mandane. c. 1765 by Tilly Kettle (Wikimedia)

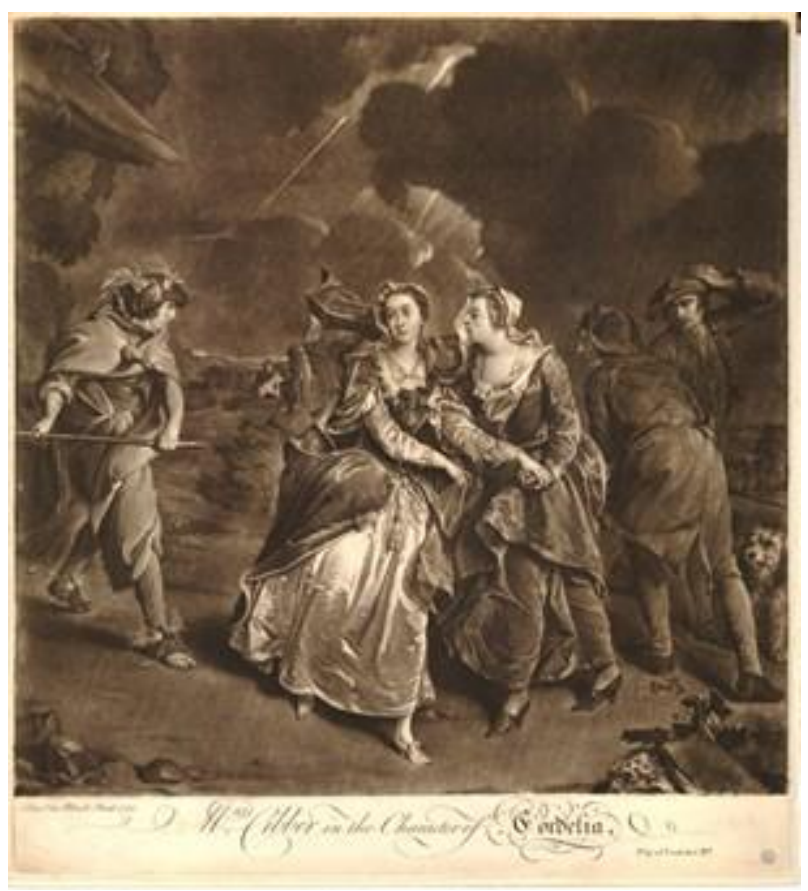

Figure 2: Mrs. Cibber in the character of Cordelia c. 1755. Mezzotint by Peter van Bleeck (Wikimedia)

Yates's departure from the Cibberian mould was as complete as Mandane's departure from Idame. The play and its paratexts emphatically establish Mandane as an unerotic object. Yates even calls attention to this unromantic role in the epilogue written for her, mock-complaining that: 
How cou'd this bard successful hope to prove?

So many heroes, --- and not one in love!

No suitor here to talk of flames that thrill;

To say the civil thing --."Your eyes so kill!" ---

No ravisher, to force us --- to our will! (Murphy, Epilogue 8-12)

But this mock-complaint is a reminder that Mandane's plot follows a different trajectory than that of her tragic sisters'. Rather than a plot revolving around sexual conquest or sexual fault, Mandane's is maternal and national. The Orphan of China stages Mandane's heroic struggle between her duty to her husband, state, religion and prince on the one hand and her 'natural' maternal passion on the other. This tension gives the tragedy its emotional pull and its resolution creates a new kind of tragic heroine. This is revolutionary. Not only does Murphy make maternal and domestic bonds, rather than sexual desire, the counterweight to public duty, but he also weights the struggle in favour of those "domestic pangs." Maternity is far stronger than all the patriarchal forces aligned against it: Murphy and Yates dramatize a new vision of maternity and celebrate the power of familial love to unite rather than divide the nation. Murphy and Yates collaborate to turn a character originally presented as a disruptive force within the patriarchal world of the play into a proto-Romantic saviour. Mandane is thus not just the spectacular focus of a feminocentric tragedy, but, unusually for eighteenth-century tragedy, the play's moral compass. ${ }^{19}$ In transforming the character of Idame into Mandane, Murphy turned his adaptation of Orphelin into a completely new play, for Mandane differs so markedly from Voltaire's Idame as to be a completely new character, one that changes the emotional and didactic thrust of the play.

This stark departure is clear when looking at the characterisation of Idame in contrast to that of Mandane. Idame is defined by her guilty romantic past and her sexual desirability. Her heart knows more than maternal love: in the play's opening scene, Idame boasts of a previous love affair with Ghengis Khan:

He lov'd me; and perhaps my foolish heart

Approv'd his love: perhaps it was my pride

To tame this lion shackled in my chains,

To our soft forms to bend his savage grandeur,

To polish with our virtues his rough soul,

And make him one day worthy to be rank'd

Among the number of our citizens.

He would have serv'd the state he has destroy'd;

And He we scorn'd has brought on all our woes.

Thou know'st, the fierceness of our jealous people,

The ancient honours of our arts and laws,

Our holy faith, thrice sanctified and pure,

And the long glories of a hundred ages,

All, all forbad, with one united voice,

A base alliance with the barb'rous nations. (Francklin I.i.56-70)

"He would have serv'd the state he has destroy'd": Idame's sexual attractiveness, her power to inspire love, is presented as a civilising force, but at the same time it suggests that Ghengis Khan's fury is driven by his thwarted desire, not just imperial conquest. Denied Idame, he takes all China; overawed by Idame, he finally agrees to recognize the laws she refuses to violate. 
Idame's desirability is the fulcrum on which the play balances. Her sexual arrogance is to blame for China's subjection, and she must atone for it. Her marital chastity, therefore, is antidote to that youthful arrogance. Voltaire's play dramatizes the invasion and gives us Idame at the peak of her youth and beauty. Murphy's Orphan of China is set twenty years later, on the eve of the rebellion against the established usurper: there is no conjuring of the young Mandane. Indeed, the "flashback" scene is given to Zamti/Garrick, who recalls for the audience his heroic actions during the initial invasion. Whereas Idame's maternal care is devoted to her infant, the recent pledge of her marital love, Mandane has spent the last twenty years raising the orphan prince and mourning her lost son. Hers is a maternal rather than a sexual passion.

Unlike Idame, Mandane is not fatally desired, nor does she exhibit fatal desires of her own. Her maternal love is consistently lauded, even while her compatriots are urging her to repress it to protect the state. But Mandane refuses to repress her love; she is not passive and she will not apologise for her desires. She acts decisively throughout the play, and forces others to react to her. Mandane asserts that the maternal tie is stronger than state or church: "Mine is a mother's cause - mine is that cause / Of husband, wife, and child; - those tend'rest ties! / Superior to your right divine of kings!" (Murphy 33). This revolutionary claim is allowed to stand. While Mandane's disruptive force is occasionally decried, it is never really challenged. Zamti urges Mandane to follow his example, to:

... rank with those, who, from the first of time,

In fame's eternal archives stand rever'd

For conqu'ring all the dearest ties of nature,

To serve the gen'ral weal. (Murphy 33)

This call to serve the state at the expense of the personal is certainly the thrust of Voltaire's didactic theme, but Murphy's version instead privileges Mandane's refusal to disavow her "domestic pangs." For her, the common weal is not just the state but also the family. She will only compromise so far. She answers Zamti's plea with her own:

\section{... Come lead me hence}

Where I may lay down life to save Zaphimri,

- But save my Hamet too. - Then, then you'll find

A heart beats here, as warm, and great as thine. (Murphy 33)

If Zamti helps her save her boys, then he'll find a heart as great as the stoic statesman's: "save Zaphimri / - But save my Hamet too." The family props up the state. Mandane reframes Zamti's stark binary: family or state becomes state as family. She teaches Zamti, and through him the audience, that the "dearest ties of nature" are bonds to be nurtured-not conquered. Zamti's may be the "capital part," but the play encourages us to see with Mandane's eyes and to feel with her heart. "[T] he wild fury of a mother's love" (32) is not here a disruptive force: it is a force of nature. It is the only language that Tartars and Chinese, English and French, share; it is the only thing we all have in common.

Murphy's refocusing of the play from public virtue to private woe is seen from the very first lines. Thomas Francklin's translation of Voltaire's version opens with Idame privileging the public horrors over her private woes:

Can there, in this sad day of desolation,

In this dire hour of carnage and destruction, 
When ev'n this palace, open to the Tartars,

Falls with the world beneath barbarian hands,

Can there, amid this heap of publick horrors,

Remain for me fresh cause of private woe? (I.i.1-6)

The implied answer to Idame's rhetorical question is no. Yes, there may be tragedy to come, but the "heap of publick horrors" far outweigh her personal cause of woe, and her personal beauty saves herself and her husband from harm. For Mandane, the answer is a resounding yes, and she not only holds her "ceaseless woe" to be equal to the public horrors, but to be worthy of public as well as private mourning. When the play opens, Mandane is mid-rage, sobbing that "still this heart / Must throb with ceaseless woe" (Murphy 1). She refuses to "suppress these unavailing tears" (Murphy 1), asserting that "This heart, revolting from the public cause, / Bleeds from a private source" (Murphy 2). Far from striving to conquer the "dearest ties of nature" (Murphy 33), Mandane strengthens them, watering them with her tears. If Ghengis Khan's love and his revenge is the subject of Voltaire's play, Mandane's heart and its ceaseless woe is the subject of Murphy's. While this shift of focus was not what Francklin had in mind when recommending some alterations to Voltaire's plot, and probably was not the shift in focus that Garrick expected, it was a triumph. The Orphan of China moved audiences to tears - not of sentimental pity, but of admiration. In Mandane, they finally had a heroine for whom there was no need to blush: a woman who was both passionate and faultless, an active mother rather than a passive lover.

\section{Repertory rivalries: Idame, Mandane and Lady Randolph (1759)}

By the time Orphan of China was finally ready to debut, Covent Garden was well prepared to respond to Drury Lane's new tragedy. The two theatres royal enjoyed a repertory rivalry in which each attempted to lure away the other's audience through aggressive programming. This happened through rival productions of the same play, such as the Romeo and Juliet battle of 1750 , or through rival productions of plays with similar characters, such as the rival Zaras of 1736 , or through plays with similar plots or by the same playwright. Covent Garden's strategy against The Orphan of China, Murphy's first tragedy, was to (attempt to) match plots. The rival theatre revived John Home's Douglas (1756) with Georgeanne Bellamy as Matilda, Lady Randolph, the eponymous character's grieving mother. Covent Garden clearly anticipated a battle of the she-tragedies and pitted its biggest female star against Mary Ann Yates. However, just as Garrick's star vehicle did not go to plan, Covent Garden's attempt to rival the new play and its cast also backfired. The juxtaposition served to distinguish Mandane from her predecessors rather than conflate the maternally-mad. The head-to-head comparison helped audiences see the novelty of The Orphan of China's Mandane and Mary Ann Yates. Douglas's Matilda is, like Mandane, the cynosure of the play. Both are grieving mothers. Both live in countries menaced by foreign (and barbarian) invasion. But there the similarity ends. Lady Matilda Randolph is a typical she-tragedy heroine: she is not the agent of her own plot, but the desirable object through which the hierarchy of masculine authority is reconfirmed. Within the first scene, the audience learns that Matilda has lost, in quick succession, her (secret) husband, brother, infant son, and father. After an attempted rape/abduction (by the disguised Glenalvon, the Iago-esque heir to Lord Randolph), Matilda gives into commands that she marry, and she gives her hand, but expressly not her heart or her body, to Lord Randolph. The play is explicit that this marriage remains unconsummated. Matilda opens the play apostrophizing her dead husband: "O Douglas! Douglas!" (I.i.8) and goes on to assure him (and audiences) that: 


\title{
... tho' I am call'd
}

\author{
Another's now, my heart is wholly thine. \\ Incapable of change, affection lies \\ Buried, my Douglas, in thy bloody grave. (I.i.18-21)
}

While Lord Randolph does not know the secret of his wife's alienated affections, believing her excess of mourning is for her dead brother, he feels her sexual rejection keenly, complaining:

I never ask'd of thee that ardent love,

Which in the breasts of fancy's children burns.

Decent affection and complacent kindness

Were all I wish'd for; but I wish'd in vain. (I.i.90-93)

As in Voltaire's Orphelin, the opening scene lays out the heroine's erotic past in order to present it as the cause of the ensuing tragedy. Her secret first husband and beloved brother have died in battle; her infant child was lost at sea and is presumed dead; her father died from grief; her unloved second husband is bellicose due to sexual frustration; and his heir is jealous of Randolph's political and personal conquests. When the lost son returns, tragedy ensues.

Matilda is thus the fulcrum of a complicated erotic and homosocial nexus: her brother's love for the (disguised) Douglas inspires her conjugal love; Glenalvon's (disguised) lust for Matilda poisons his relationship with Randolph. Matilda's own identity is also in flux: she is maid and wife, mother and virgin simultaneously. Matilda lost her infant son the day he was born: she has never known the joys of motherhood; her husband has been waiting seven years to know the joys of a husband. But more importantly for the play's complicated plot, Matilda's maternal love is inseparable from the conjugal lust that created young Douglas. He is the ghosted image of his dead father - the passage of time exists only to make him his father's double, while Matilda, "Incapable of change," has been vitrified in her ageless grief and remains as she was when she lost her love. The (mis)recognition of Matilda's maternal love as lust leads to the play's tragedy. Her maternal passion is mistaken by her jealous husband for sexual attraction, but her passion is ignited by her son's resemblance to his lost father, for whom Matilda still yearns: despite her protestations of innocence, Lady Randolph's desire for Douglas is not pure. Her last-act off-stage suicide is an acknowledgement of her culpability in the growing body count and complete breakdown of succession. Glenalvon is dead, Douglas is dead, and Lord Randolph is abdicating his rule to go "straight to the battle . . . . . . and hopes he never shall return" (V.346, 51). Lady Randolph divides and destroys the nation: she is a force for chaos.

Douglas's Lady Randolph is a familiar she-tragedy heroine: beautiful, culpable, doomed. She shares the stage with scores of other wives and mothers who have betrayed or been betrayed by their first loves. In Walpole's Mysterious Mother (1768), the maternal is contaminated by the sexual by pre-meditated incest: as in Douglas, physical resemblance between son and father leads to a conflation of the maternal and carnal. In another vein, the loss of her husband drives Medea to infanticide: no longer a wife, she cannot continue as a mother. Almeria, the eponymous Mourning Bride (1697), occupies the same dual status territory as Matilda, mourning her lost secret husband, but unable to publicly own her status as wife. Idame, whose secret love-affair with Ghengis Khan creates the complicated tangle of personal passion and national conquest, fits this pattern as well, making Douglas a logical choice to mount against Murphy's adaptation of the Orphelin story. But Mandane, unlike her tragic sisters, is not motivated by remembrance of lost love; the sight of her grown son does not transport her to her wedding night or arouse visions of conjugal bliss. Mandane, like Matilda, lost her infant 
son, but she has still been a mother. Mandane may have a secret son, but her maternal status is unwavering throughout the play.

The Orphan of China's tragedy, then, like Douglas's, stems from an act of misrecognition, but again, the structural similarity is superficial. Both Mandane and Zamti recognise Hamet as their son. There is no sexual jealousy. The only jealousy expressed is between the two "orphans" who contest with each other for the right to grieve their parents, to carry on Mandane's task of nurturing private woe for the public good. Mandane's wayward passions do not cause her death: she chooses to sacrifice herself rather than sacrifice a child - any child - for political expediency. Hamet's life is as precious as the prince's; Zaphimri is as worthy of a mother's love as is her biological son. Mandane sees no virtue in "conquering the dearest ties of nature." For her, the personal is the political; the family and the state must rise, or fall, together.

Garrick's gamble on The Orphan of China paid off; just not as he expected it to. Arthur Murphy's radical departures from Voltaire's plot were to remove the love plot and to age the Orphan(s) of China from infants to young men. ${ }^{20}$ While one or both of these dramaturgical decisions may have been taken to insure the play against the failing health of Susannah Cibber, the revised play instead made Yates a star and created a new line of passionate femmes fort: women who aroused audience's admiration, not just their pity. Mandane's righteous fury, her refusal to be silent and her refusal to accept that personal sacrifice is a public virtue, transformed what Voltaire described as "the weakness of a mother" (Francklin III.iii.50) into triumphs for Mandane, Murphy, and Mary Ann Yates.

Yates learned her craft while serving as Susannah Cibber's general understudy, but in a period in which performance was taught through imitation and repetition, Yates chose to break with convention and offer novel interpretations. Yates created the new femme fort by playing to her physical and vocal strengths, by embodying this new role. Yates continued to shine as a femme fort for the rest of her career, reinterpreting established roles and creating new heroines. ${ }^{21} \mathrm{Her}$ success as Mandane opened up new leading roles for her, including King John's Constance, The Fair Penitent's Calista, and Lady Macbeth, all of which she imbued with her own power and agency. She also responded to Georgeanne Bellamy's attempt to instigate a rivalry by adding Lady Randolph to her repertoire. New femmes fort roles were also written for her, including new interpretations of Margaret of Anjou, Dido, Medea, Electra, and the Countess of Salisbury. In 1768 she created a new Mandane, the heroine of John Hoole's Cyrus, which replaced Murphy's Mandane in the repertoire. By 1769, Yates's star turns were powerful enough to impact the ton's social calendar: "Having places in the Pit at Covent Garden went to see Mrs Yates do Medea in which she is inimitably great. My strong desire to see her in this character was one reason of continuing in town so long. Read her part before the play began" (Neville qtd. in Stone 1393). ${ }^{22}$ For men of the ton like Neville, the season is determined by Yates's appearances. ${ }^{23} 1769$ also saw a review of another Yates femme forte, Electra. After a lengthy examen of Francklin's translation of Voltaire, the review concludes with a single half sentence about the performance: "and as to the representation, we shall only say, that Mrs. Yates was inimitable in Electra" (London Magazine 119). Neville's diary and The London Magazine's review wholly focus on Yates's part, Yates's performance; nothing else on stage matters. Yatesean characters drive plots forward and make things happen. Rather than passively suffer, a Yates heroine will demand Justice and wreak Vengeance. She did, rather than let herself be undone. Yates's strength and physical command of the stage were central to her performance style and her appeal to audiences. She transformed she-tragedy by creating a 
line of haughty queens and commanding lovers, of using the genre to celebrate great women and condemn their unjust fates. Thomas Davies wrote admiringly of her characteristic "grandeur of mind, pride of behaviour, resentment of injury, and dignity of action" (Davies 132). William Godwin, an astute judge of the sublime, concluded that: "Mrs. Siddons was great only as the occasion sustained her; but Mrs. Yates was great because, by the habit of her soul, it was impossible for her to be otherwise" (qtd. in Campbell 65)

\footnotetext{
${ }^{1}$ Prior to the premiere of The Orphan of China, Murphy's only plays were farcical afterpieces: The Apprentice (1756) and The Upholsterer (1758).

2 "G.F. Theatricus" assured readers that "The Loss of Mrs. Cibber too must now be less deplored, while Mrs Yates appears ..." (Public Advertiser, 11 March 1766).

${ }^{3}$ Yates's image is captured in Thomas Davies's account of a "characteristic" performance: "Mrs Yates acted so characteristically, displayed such grandeur of mind, pride of behaviour, resentment of injury, and dignity of action, that the other characters seemed to be totally eclipsed; the audience was full of admiration of the
} unfortunate queen, who, in her last scene, seemed to triumph over all her enemies" (132).

${ }^{4}$ See Bruce for an overview of English appropriation of Voltaire.

${ }^{5}$ For a detailed and incisive analysis of Orphan's development, especially from the Chinese source Orphan of Zhao, see Thorpe.

${ }^{6}$ Baker et al. attribute the play to Thomas Francklin: “Trag. Translated from Voltaire. Printed in Dr. Franclin's [sic] edition of that author's works" (106).

${ }^{7}$ This was no doubt a bid for preferment from Garrick, but Garrick did not rise to the bait, accepting the flattery but refusing the commission. Francklin would not have a play accepted for performance until 1766, when his Yates-driven Earl of Warwick premiered. Its success paved the way for Orestes (1769), Electra (1774), and Matilda (1774), all new she-tragedies with powerful heroines and all vehicles for Mary Ann Yates.

${ }^{8}$ See also Zuroski Jenkins, esp. Chapter 2, "The Chinese Touchstone of the Imagination,” pp. 66-104 in which she argues that chinoiserie functions as "culturally privileged markers of English taste" (66).

${ }^{9} \mathrm{His}$ Richard III is an exception to this rule, but Garrick curated his stage presence to encourage audiences to love and admire, rather than fear and despise him. Lusigan is a case in point: he is the highest-ranking Christian character, and although only appears in Act 4, Garrick always gave himself top billing.

${ }^{10}$ Given the original character names in use as late as 1759, and Murphy's correspondence with Voltaire, I have assumed that Murphy is working from his own translation of Orphelin, although he may also have had a hand in Francklin's translation. For a similarly fraught translation history, see Aaron Hill's Zara (1736).

${ }^{11}$ For an overview of this process, see Ou. For the Muphy-Garrick correspondence, see Boaden.

12 Richard Cross qtd. in The London Stage, vol. 4, pt. 2, p. 704.

${ }^{13}$ See Brooks for Cibber's contract and repertory rights.

${ }^{14}$ The London Stage and extant newspaper bills identify performances on 21, 23, 25, 28 April and 1, 3, 5, 8, 12, 19 May. Genest suggests a "dozen" performances and Murphy himself insists on 13.

15 The play was well received: An Account of the New Tragedy of the Orphan of China and its Representation was advertised for publication on 24 April, 1759, just three days after the premiere; the Prince of Wales and his family bespoke a performance and attended on the $28^{\text {th }}$ April, and William Whitehead's prologue to the play was published on the 1st May. Murphy's Orphan of China was performed regularly through the 1760s, until it gave way to Hoole's Cyrus (1768) in which Yates played a new version of Mandane.

${ }^{16}$ See Murphy to Garrick, 3 Feb 1759: "The part I am willing to reduce to the usual length; you have had the play to your own time, and I cannot think that I am well treated at present." It is notable that Murphy's Timurkan is a much smaller role and his Zamti a much larger one than the corresponding roles in Voltaire's version of the story (qtd. in Boaden 97).

${ }^{17}$ L'Orphelin de la Chine gives Idame a female confidante, Asseli. There is no equivalent role in Murphy.

${ }^{18}$ For detailed analysis of the role of Chinoiserie and costume, see Zuroski Jenkins, Ou, and Yang, esp.

"Luxury, Moral Sentiment, and The Orphan of China" pp. 148-53 in Performing China.

${ }^{19}$ In this, Orphan of China resembles contemporary reform comedy far more than tragedy. Murphy, who was patronized and supported by Colley Cibber, follows the Poet Laureate's template in creating a closed social world in which a morally unimpeachable woman corrects male behavior and restores right rule through the force of her moral example (cf. The Careless Husband).

${ }^{20}$ In his lengthy letter to Voltaire (appended to the first print edition of the play), Murphy spends surprisingly little time on Mandane, the character most changed in his revision. Instead he critiques Voltaire's Ghengis Khan, who he describes as "whining for a Mandarin's wife" (92) "in the very moment of overwhelming a whole nation, usurping a crown, and massacring the royal family" (91). But he makes oblique reference to his 
reforming mission: "Within the compass of my reading, there is hardly a bad man in any play, but he is in love with some very good woman" (92). Murphy's heroines deserve - and receive-better.

${ }^{21}$ William Godwin's description of her Violante in Centlivre's The Wonder is a case in point. He concludes his lengthy and rapturous description with this acknowledgment: "The condescension in a graceful and wayward beauty would have been comparably nothing,- - with Mrs. Yates's figure and demeanour, it laid the whole audience, as well as her lover, at her feet." (qtd. in Campbell 65).

${ }^{22}$ Neville MS Diary 29 Mar 1769, qtd. in The London Stage, v.4, pt. 3, p. 1393.

${ }^{23}$ This performance, billed as a benefit for Yates's husband, is another example of Yates's strength and savvy. She withheld the role until the benefit performance and refused to appear on stage in the week leading up to it, even starting a (faux) paper war over her refusal to appear in Georgeanne Bellamy's benefit the night before Medea in order to preserve her energy, assuring the public that "it will be impossible for me to play two such fatiguing Parts as Hermione and Medea two Nights successively" (Public Advertiser, 11 March 1769). 


\section{Works Cited}

Baker, David Erskine. Biographia Dramatica; or, a Companion to the Playhouse, vol. 1, London, 1782. ECCO.

http://find.galegroup.com/ecco/infomark.do?\&source=gale\&prodId=ECCO\&userGro upName $=$ univbri\&tabID $=$ T001\&docId $=C W 113052628 \&$ type $=$ multipage \&contentSet $=$ ECCOArticles\&version=1.0\&docLevel=FASCIMILE.

Baker, David Erskine, Isaac Reed and Stephen Jones. Biographia Dramatica, vol. 2, London, 1812. HathiTrust, https://hdl.handle.net/2027/uc1.b3506121.

---. Biographica Dramatica; or, A Compantion to the Playhouse. vol. 3 London, 1812. HathiTrust, https://hdl.handle.net/2027/uc1.b3506122.

Boaden, James. The Private Correspondence of David Garrick with the most celebrated persons of his time. London, 1831 HathiTrust, https://hdl.handle.net/2027/umn.31951002024295k.

Brooks, Helen. 'Your sincere friend and humble servant': Evidence of Managerial Aspirations in Susannah Cibber's Letters,' Studies in Theatre and Performance, vol. 28, no. 2, 2008, pp. 147-59. Taylor \& Francis Online. DOI: 10.1386/stap.28.2.147_1.

Bruce, Harold Lawton. Voltaire on the English Stage. U of California P, 1918.

Campbell, Thomas. The Life of Mrs Siddons, vol. 1, London, 1834. HathiTrust. https://hdl.handle.net/2027/uc1.\$b113194.

Carlson, Marvin. The Haunted Stage: Theatre as Memory Machine. U of Michigan P, 2001.

Davies, Thomas. Memoirs of the Life of Garrick, vol. 2, London, 1784. ECCO. http://find.galegroup.com/ecco/infomark.do?\&source=gale\&prodId=ECCO\&userGro upName $=$ univbri\&tabID $=$ T001 \&docId $=$ CW 102486220\&type $=$ multipage $\&$ contentSet $=$ ECCOArticles \&version=1.0\&docLevel=FASCIMILE.

Francklin, Thomas. The Orphan of China. London, 1756. ECCO. http://find.galegroup.com/ecco/infomark.do?\&source=gale\&prodId=ECCO\&userGro upName $=$ univbri\&tabID $=$ T001\&docId $=$ CW $114106926 \&$ type $=$ multipage \&contentSet $=$ ECCOArticles \&version=1.0\&docLevel=FASCIMILE.

Genest, John. Some Account of the English Stage, from the Restoration in 1660 to 1830. Bath, 1832. HathiTrust. https://hdl.handle.net/2027/hvd.32044100891357.

Home, John. Douglas: a Tragedy. As it is acted at the Theatre-royal in Covent-Garden. London, 1757. ECCO. http://find.galegroup.com/ecco/infomark.do?\&source=gale\&prodId=ECCO\&userGro upName $=$ univbri\&tabID $=$ T001\&docId $=$ CW3314475162\&type $=$ multipage $\&$ contentSe $\mathrm{t}=\mathrm{ECCOArticles} \&$ version=1.0\&docLevel=FASCIMILE. 
The London Magazine; or the Gentleman's Monthly Intelligencer, vol. 38 March 1769, London, 1769. ProQuest, https://search.proquest.com/docview/5236559?accountid=9730.

The London Stage, 1660-1800; a calendar of plays, entertainments \& afterpieces. Edited by George Winchester Stone, Jr., vol. 4, part 2, Southern Illinois UP, 1962.

Murphy, Arthur. The Orphan of China, London, 1759. ECCO.

http://find.galegroup.com/ecco/infomark.do?\&source=gale\&prodId=ECCO\&userGro upName $=$ univbri\&tabID $=$ T001\&docId $=$ CW $114019855 \&$ type $=$ multipage $\&$ contentSet $=$ ECCOArticles\&version=1.0\&docLevel=FASCIMILE.

Ou, Hsin-yun. "Gender, Consumption, and Ideological Ambiguity in David Garrick's Production of The Orphan of China." Theatre Journal, vol. 60, no. 3, 2008, pp. 383407. JSTOR. www.jstor.org/stable/40211069.

Public Advertiser, 19 Dec 1755, Issue 6599. Burney Collection Newspapers. Gale Document Number Z2001071111 http://find.galegroup.com/bncn/infomark.do?docType=LTO\&docLevel=FASCIMILE $\&$ prodId $=\mathrm{BBCN} \& \operatorname{tab} I \mathrm{D}=\mathrm{T} 012 \&$ type $=$ multipage $\&$ version $=1.0 \&$ retrieveFormat $=\mathrm{MUL}$ TIPAGE_DOCUMENT\&userGroupName=univbri\&docPage $=$ article \&docId=Z20010 71111\&contentSet=LTO\&source=gale .

Public Advertiser, 11 Mar 1766, Issue 9784. Burney Collection Newspapers. Gale Document Number Z2001109779 http://find.galegroup.com/bncn/infomark.do?docType=LTO\&docLevel=FASCIMILE $\&$ prodId $=$ BBCN\&tabID $=$ T012\&type $=$ multipage $\&$ version $=1.0 \&$ retrieveFormat $=$ MUL TIPAGE_DOCUMENT\&userGroupName=univbri\&docPage .

Public Advertiser, 11 Mar 1769, Issue 10723. Burney Collection Newspapers. Gale Document Number Z2001129172 http://find.galegroup.com/bncn/infomark.do?docType=LTO\&docLevel=FASCIMILE $\&$ prodId $=\mathrm{BBCN} \& \operatorname{tab} \mathrm{ID}=\mathrm{T} 012 \&$ type $=$ multipage $\&$ version $=1.0 \&$ retrieveFormat $=\mathrm{MUL}$ TIPAGE_DOCUMENT\&userGroupName=univbri \&docPage $=$ article \&docId $=\mathrm{Z} 20011$ $29172 \&$ contentSet $=$ LTO\&source $=$ gale .

Thorpe, Ashley. Performing China on the London Stage: Chinese Opera and Global Power, 1759-2008. Palgrave, 2016.

Yang, Chi-ming. Performing China: Virtue, Commerce, and Orientalism in EighteenthCentury England, 1660-1760. Johns Hopkins UP, 2011.

Zuroski Jenkins, Eugenia. A Taste for China: English Subjectivity and the Prehistory of Orientalism. Oxford University Press, 2013. 